\title{
ADDENDA AND CORRIGENDA
}

\section{Preface}

The original version of this book appeared in the midst of the 'revisionist' wave in research on the history of the English Reformation. The Reformation debate has moved on, as 'revisionism' has given way to 'post-revisionism' but shows no signs of abating. There is no need to recount the arguments here - they are somewhat tangential to a volume specifically on the pre-Reformation church. However, one book which now epitomises Reformation revisionism must be mentioned. The first part of Eamon Duffy's Stripping of the Altars ${ }^{1}$ is a magisterial survey of devotional life in England in the fifteenth and early sixteenth centuries, as a prelude to his examination of the attack on what he calls 'traditional' catholic practices in the decades after 1530. The book is, rightly, seen as a major contribution to understanding of late medieval English spirituality and religious practices, and its first part overlaps greatly with the concerns of Catholic England. Despite its strengths, Duffy's book it has its critics, perhaps none more trenchant than David Aers. ${ }^{2}$ To my mind, Aers misrepresents Duffy's aims, failing to appreciate that the discussion of the pre-Reformation church serves precisely as a prelude to the study of the impact of change; it is not intended to be a globalising survey. Aers castigates Duffy's lack of reference to dissent, disharmony, and Lollardy, but that absence is not actually an omission. Aers also worries that Duffy's volume will prove so overwhelming that his positive picture of late medieval Catholicism will become a new orthodoxy. That certainly is a danger, to which Reformation historians do show signs of succumbing; but is unlikely to be an issue for the study of the late medieval church. There, indeed, the study of dissent and the role of Lollardy remains a major concern, and provokes lively debate, ${ }^{3}$ with no sign as yet that the interpretative rift between literary scholars and archivally-based historians is being closed, and the possibility that it is in fact becoming more entrenched, if not widening.

1 E. Duffy, The Stripping of the Altars: Traditional Religion in England, 1400-1580 (New Haven and London, 1992; 2nd edn, 2005).

2 D. Aers, 'Altars of power: reflections on Eamon Duffy's The Stripping of the Altars: Traditional Religion in England 1400-1580', Literature and History, ser. 3,3 (1994), pp. 90-105.

3 See R. Rex, The Lollards (Basingstoke and New York, 2002), for a succinct statement of the 'historical' view in contrast to the literary case presented in A. Hudson, The Premature Reformation: Wycliffite Texts and Lollard History (Oxford, 1988). 
Another volume of translated sources has appeared which throw light on parish life and clerical relations with the laity in England between the thirteenth and the fifteenth centuries, and thereby illustrates some of the concerns addressed in the present volume: J. Shinners and W.J. Dohar, eds, Pastors and the Care of Souls in Medieval England (Notre Dame, IN, 1998).

\section{Introduction}

n.4 See also R.N. Swanson, 'Unity and diversity, rhetoric and reality: modelling "the Church", Journal of religious history, 20 (1996), pp. 156-74

n.13 Add: R. Marks and P. Williamson, eds, Gothic: Art for England, 1400-1547 (London, 2003).

n.22 See also R.N. Swanson, 'Prayer and participation in late medieval England', Studies in Church History, 42 (2006), pp. 130-9.

n.90 The discussion of the Lynn accounts is in R.N. Swanson, 'Urban rectories and urban fortunes in late medieval England: the evidence from King's Lynn', in The Church in the Medieval Town, ed. T.R. Slater and Gervase Rosser (Aldershot and Brookfield, 1998), pp. 100-30.

\section{Documents}

p. 52 n.6: The publication of the Wycliffite sermons has now been completed: A. Hudson and P. Gradon, eds, English Wycliffite Sermons, 5 vols. (Oxford, 1983-96). A new and complete edition of Mirk's Festial (edited by Sue Powell) is imminent in the publications of the Early English Text Society.

p. 78: The discussion here over-stresses the seclusion of the celebration of the mass. Masses held at side and subsidiary altars, or in private oratories, would be much more accessible, and provide much more immediate and intimate contact with the sacred.

p.166, no.16: I have seen citations of this document which suggest it has been misunderstood. It should be stressed that this list is only an extract from a much lengthier record of grants of such licences extending through the whole of Scrope's pontificate.

p.176, n.6: Finucane's work, while still important, has been superseded as a general discussion of pilgrimage by D. Webb, Pilgrimage in Medieval England (London and New York, 2000).

p.177, n.10: For my subsequent work on Lynn, see above, Introduction n.90.

p.178, n.15: The pamphlet relating to Hailes has now been found: Oxford, Bodleian Library, Dep.d.324.

p.188, no.20 (ix-xxiv): These extracts have a consistent error in the translation, as an object lesson in not succumbing to expectations and assumptions. References to 'leftover wax' or 'recovery of wax' derive from a 
misunderstanding based on ignorance of a particular local practice at Ely cathedral. They should be read as 'sales of silk', the selling of souvenir silk necklaces of the shrine of St Etheldreda known as 'St Audrey chains' (see B. Nilson, Cathedral Shrines of Medieval England(Woodbridge, 1998), pp. 155-6). I had qualms about the translation when working on the documents, but in my ignorance of Ely's souvenir trade tried to make the references conform to a practice I had found elsewhere, and assumed that these were garbled (but consistently garbled) references to sales of donated or residue wax matching those found in other accounts.

p.206, no.27: While following the template of leases entered into by St Anthony's hospital (except that it amalgamates a number of collectorates), this may not actually be an agreement to distribute indulgences. By this date papal indulgences were no longer to be proclaimed, although the collecting machinery continued to function: see R.N. Swanson, Indulgences in Late Medieval England: Passports to Paradise? (Cambridge, 2007), pp. 494-7

\section{Note on the documents}

My main aim has been to let the documents speak for themselves. For that reason, I have not given extensive commentaries, or sought to explain every obscure reference. In each section, I have limited the commentary to a brief introduction, which along with discussion in the Introduction provides access to further literature and points out the main features of the sources. Obviously, the available literature on several aspects is immense: I have not sought to cover everything. The works referred to will generally provide a route to further reading; for a large-scale bibliography (to 1989) on the late medieval English Church, see my Church and Society in Late Medieval England (a bibliographical update is in the 1993 paperback version).

Translation is necessarily interpretation. I have sought in the treatises to provide a fluent translation, within the limitations of the texts. For the more administrative material, the translation is of course more formal, and more stilted. In general, I have translated complete documents, or those fragments of documents dealing with the relevant issues (accounts, in particular, are not always printed in full, given the extensive range of their contents). Where I have made cuts within a document, they are generally indicated by '...' Minor additions to wording to clarify a text are not usually marked; others - curtailed dating clauses, or additions to clarify a reference - are incorporated in square brackets. Some of the documents, while primarily in one of the translated languages, contain odd words or phrases from another; where it seemed important to note that distinction (particularly in some of the tracts), I have printed those sections in italics. However, where there are lists which are basically bilingual, the switch has not generally been indicated. In a few instances, I have not been able to modernise placenames, which are therefore given in italics. To make some of the longer documents more 'user-friendly', I 
have silently added paragraphing where it seemed appropriate. For the same reason, in some instances numbers which appear in figures in the original texts have been slightly converted into words; while different spellings of the same surname within a document (or entry in a run of documents) have been silently standardised. I have not corrected the arithmetic in the financial statements: usually it adds up, but there are occasionally discrepancies, and sometimes oddities in the calculations which might not seem immediately explicable but which become clear on closer inspection.

A final word is necessary about the monetary system used in some of these documents. The basic units are those which constituted the English currency until 1971: a pound $(\mathscr{L})$ consisting of twenty shillings $(\mathrm{s})$, each of which contained twelve pence $(\mathrm{d})$. However, in the accounts the sums are not uniformly and neatly divided into such units: figures in pence are commonly encountered up to 40d.; sums in excess of twenty shillings are often expressed in that unit up to (sometimes beyond) 100s. Alongside this system, another accounting system dealt in terms of 'marks', equivalent to 13s. 4d., or two-thirds of a pound. Both systems may be encountered in the same document. 